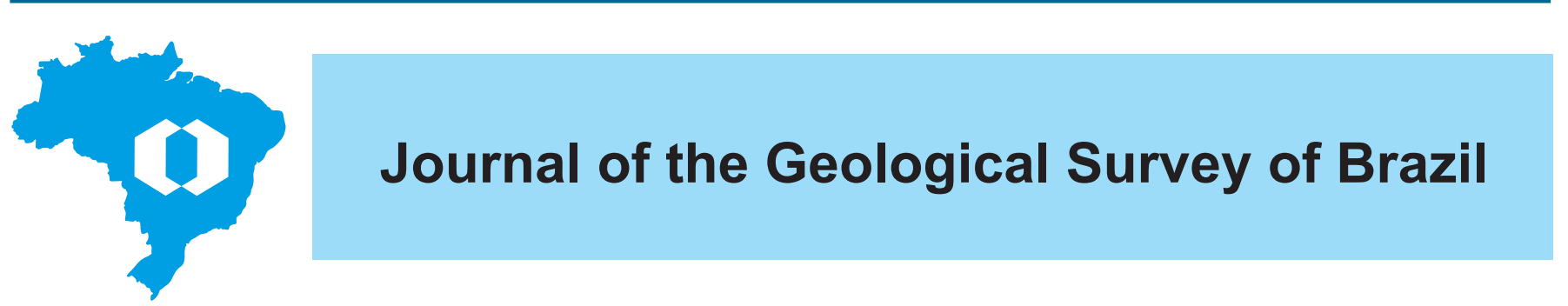

\title{
Three hundred years of geodiversity in the Historic Center of the Gold City, Cuiabá, Brazil
}

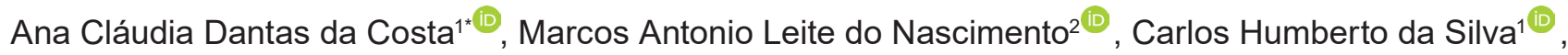 \\ Renato Blat Migliorini ${ }^{1}$
}

${ }^{1}$ Faculdade de Geociências, UFMT - Universidade Federal do Mato Grosso, Av. Fernando Correa da Costa, 2367, Boa Esperança, Cuiabá - MT - CEP 78060-900

${ }^{2}$ Departamento de Geologia, UFRN - Universidade Federal do Rio Grande do Norte, Campus Universitário S/N, Lagoa Nova - Natal - RN - CEP: $59078-970$

\section{Abstract}

Gold was abundant in the city of Cuiabá and was the starting point for is emergence and development. Bandeirantes (explorers/fortune hunters during the colonial period), mostly coming from São Paulo, made their expeditions into inland Brazil firstly to capture and enslave natives and, in this process, discovered important alluvial deposits associated with the rivers in the region. Today, this precious metal is still present and being prospected in the Baixada Cuiabana region, and is found preserved (impregnated and visible) in the plaster of the walls of the Church of Nossa Senhora do Rosário e São Benedito, for example. Many buildings in the central areas were built and adorned with ex situ geological material such as ironstone and blocks of milky quartz, and some of these buildings are identified in this work as an example of the use of geodiversity as a constructive and historical element. Ironstone is described as a solid, reddish sedimentary rock resulting from a chemical alteration process (lateritization), and the quartz blocks come from gold veins that cut the rocks of the Cuiabá Group, in the Baixada Cuiabana region. In addition to these materials that are present in some locations and represent geodiversity elements, an in situ example of geodiversity is described. It is an exposed geological fault that stands out in the landscape, located in an aligned hill where historic constructions were built. Because it is of unique geoscientific interest and preserved within the central urban boundary of the city of Cuiabá, this place can be considered the first geosite, which is described in the present work.

\section{Article Information}

Publication type: Research papers Received 20 October 2020 Accepted 7 May 2021 Online pub. 7 June 2021 Editor: Katia Mansur

\section{Keywords:}

Gold,

Geodiversity,

Ironstone

${ }^{*}$ Corresponding author Ana Costa

E-mail address: anacos@gmail.com

\section{Introduction}

The name Cuiabá, capital of the state of Mato Grosso, Brazil, derives from the indigenous word Cuyaverá, which means 'bright otter', one of the small animals that lived in these very distant lands. The history of this city begins with an element of geodiversity, with the arrival of explorers in the region searching for primary and alluvium gold, and became known as the Gold City. In the historical evolution of this city, geological materials were used, which are recognized in building restorations in its historic center. As it is in other urban centers in Brasil (Nascimento et al. 2018; Del Lama 2019) (Nascimento et al. 2018; Del Lama 2019), geodiversity is present in various moments of the history of Cuiabá.

The present work aims to describe elements of geodiversity in the central area of Cuiabá. First, the starting point for the development of Cuiabá occurred with the discovery of alluvial gold in the Coxipó and Cuiabá rivers. The historic center grew from the orderly construction of buildings located in prominent locations, such as the top of hills and mounts, which are composed of metarenites of the Cuiabá Group.

\section{Materials and methods}

This research had the purpose of identifying locations where there are geodiversity elements (stony materials) in the center of Cuiabá, MT. Identification of the geodiversity characteristics was based on Silva and Nascimento (2016).

The places detailed in this paper are buildings where ex situ geological materials were used and, based on this cataloged data, a simplified map of the historic center and surroundings was developed, indicating the location of the buildings, which could be used as a proposed guide for the practice of geotourism.

The Institute of Historic and Artistic Heritage of Cuiabá provided bibliographic support for the search of written materials, such as the files of historic, cultural buildings that were preserved as historic heritage, as well as a vast urbanistic literature of books and theses. 


\section{Timeline and city space}

The story begins to be told from the first incursions of the Bandeirante Pascoal Moreira Cabral Leme into the lands of western Brazil. He went upstream the Coxipó River and discovered gold concentrations, starting, in 1718, the gold rush in this region. A year later, on April 08, 1719, Vila Senhor Bom Jesus of Cuiabá was founded.

With the initial discovery of gold in this region, the first mines were called "Sutil Mines", named after Miguel Sutil in his search for gold and honey. In 1734, the brothers Artur and Fernando Paes de Barros, also from the state of São Paulo, called these mines 'Mato Grosso Mines'. This name, 'Mato Grosso' (in English, thick forest), according to historical records dated to 1866, originates from: "a large extension of seven leagues of tall, thick and almost impenetrable forest". In this period, in the 1730s, the first construction built on top of a hill, on the banks of the Prainha Stream, was the Church of Nossa Senhora do Rosário e São Benedito.

In 1757, two decades after the discovery of gold in Mato Grosso Mines, the history of the mines was officially documented, where the term 'Mato Grosso' was described and identified as the location where the mines were found. In the $18^{\text {th }}$ century, the Cuiabá village belonged to the São Paulo captaincy, and in 1748 it became one of the Captaincy Terms of 'Matto Grosso'. In 1818, the village was raised to the status of town and, in 1835, Cuiabá became the capital of the province and later the capital of the state of Mato Grosso (Conte and Freire 2005). According to the records, in the mid-nineteenth century, the extraction of gold decreased drastically, and as a result, the economy went into a decline with consequent reduction in the population. Only after the implementation of railroads and telegraphs, as well as the arrival of rubber tappers, the economy resumes growing again and new constructions were built.

In the early $20^{\text {th }}$ century, the city began to be urbanized, the Prainha Stream was channeled, the banks were cemented, and bridges for cars and pedestrians were built. Thus, this river, once a large flowing river, became a trickle of water in a closed channel in the center of the avenue, today named Historiador Rubens de Mendonça Avenue (Figure 1). The city has grown from the port and this stream, and numerous buildings were erected and gave form to the central area that we see today.

On the map of the historic center (Figure 1), which was developed from maps available in library of the city hall of Cuiabá, the main buildings that comprise the proposed geodiversity route were indicated. Clockwise, one can see in Figure 1: the Presbyterian Church of Cuiabá $\left(n^{0} 1\right)$; the Palace of Instruction ( $\left.n^{\circ} 2\right)$; the Metropolitan Cathedral and Basilica of Bom Jesus de Cuiabá ( $n^{\circ} 3$ ); Church of Nossa Senhora da Boa Morte ( $\left.n^{\circ} 4\right)$; Church of Nosso Senhor dos Passos ( $\left.n^{\circ} 5\right)$; Church of Nossa Senhora do Rosário e São Benedito $\left(n^{\circ} 6\right)$; and outside the central area the Church of Nossa Senhora do Bom Despacho $\left(n^{\circ} 7\right)$.

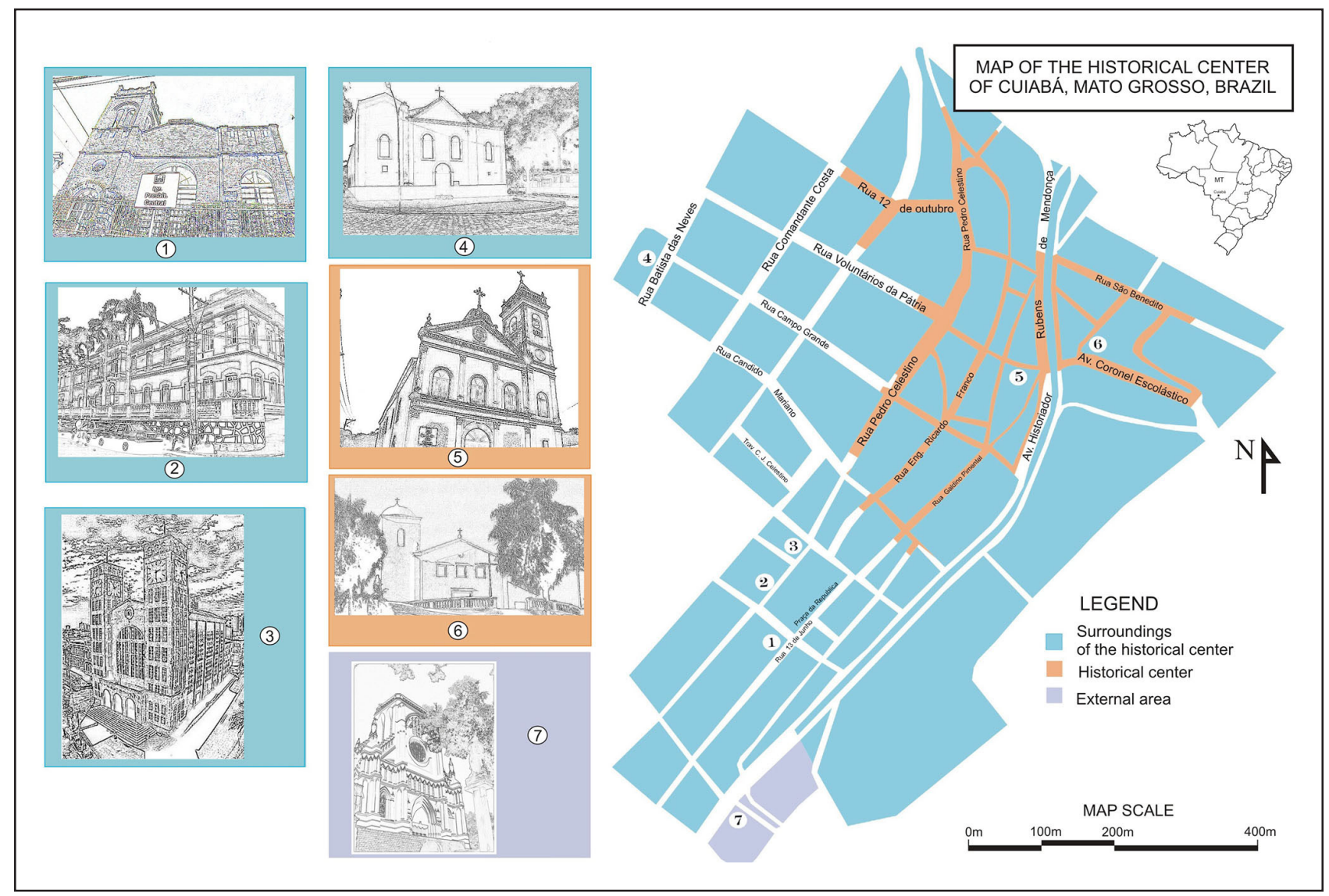

FIGURE 1. Schematic map (basic map of the City Hall of Cuiabá) of the historic center and surroundings of Cuiabá, with the location and drawings of the buildings studied in this work. (1) the Presbyterian Church of Cuiabá; (2) Palace of Instruction; (3) Metropolitan Cathedral and Basilica of Bom Jesus de Cuiabá; (4) Church of Nossa Senhora da Boa Morte; (5) Church of Nosso Senhor dos Passos; (6) Church of Nossa Senhora do Rosário e São Benedito; and outside the central area the (7) Church of Nossa Senhora do Bom Despacho.(Map source: City Hall of Cuiabá; Figures source: Ana Costa, 2020). 


\section{Ex situ geodiversity elements}

Stony geological materials can be used in urban constructions and show how important is to keep records of these places. Some works, such as that by Nascimento et al. (2018), indicate a division of geological materials into groups: historical, constructive and functional. In Cuiabá, some buildings and avenues (D. Aquino, Joaquim Murtinho avenues, Barão de Melgaço street) used ironstone, which allows to classify its use into the historical group of buildings. Ironstone is a reddish-brown arenite from the Chapada dos Guimarães region. This rock is part of the Ponta Grossa Formation (Paraná Basin) and is locally in disagreeing contact with the rocks of the Cuiabá Group.

In the place where the first movie theater of the city was built, the Cine Mundial (Gazeta Digital 2017), the first Presbyterian church of Cuiabá was erected. (Figure 2a). This building, which dates back to 1921 , is located in the block of commercial stores in the Rua 13 de Junho, the street right in the center of the city. It is an old building, with an external façade made of exposed bricks and ironstone wall, giving the place a unique beauty.

The Instruction Palace is a neoclassical building located next to the Mother Church of Cuiabá and was declared a heritage building in 1983. The Palace was built with ironstone, as well as its wall (Figure $2 b$ ), with milky quartz crystal on its foundation and adobe walls with up to $80 \mathrm{~cm}$ thick.

According to historians, the Mother Church of Senhor Bom Jesus de Cuiabá (Figure $3 a$ ) has a peculiar history of construction and de-construction until becoming as it is today. It was built in 1723 (Gazeta Digital 2017), four years after the foundation of the Vila de Bom Jesus de Cuiabá. In 1739, it was rebuilt and in 1745 it gained a bell tower. In 1826, the church was raised to the status of cathedral of the city, and 103 years later, it received another bell tower. In 1968, after 235 years of existence, it was decided to demolish and rebuild it, and only in 1973 it was finally concluded. The altar, 20 meters high, is covered with tiny tiles (Figure $3 b$ ) and was built by a Polish artist (Arystarch Kaszkurewicz).

A Baroque-style chapel, built in 1810, is the Church of Boa Morte (Figure 4a). The three altars and the whole ensemble, dated back to the colonial period, belong to the Brotherhood of Color Men, and the church was declared cultural heritage in 1987. Likewise, built in 1792, we have the Church of Nosso Senhor dos Passos (Figure 4b). Typical of the colonial period, it is located within the historic center and has ironstone and quartz fragments (from veins) on an altar built outside the chapel.

The construction of the Church Nossa Senhora do Rosário e São Benedito began in 1725 and ended five years later. Inside the church, the construction of the walls was made with thick rammed earth with $90 \mathrm{~cm}$ or $40 \mathrm{~cm}$ in width. An important detail inside the church is the presence of gold scattered on the wall. This is because the wall is exposed to the public, and was made with geological material from the Prainha Stream, from which the slaves extracted gold.

The ironstone that is present in the sidewalk and walls of the Church of Nossa Senhora do Bom Despacho (Figure 5a and $5 \mathrm{~b}$ ) and embellishes the entire external area of the Rosário Church (external walls, stairways and sideways; Figures 5c and 5 d) was a landscape work designed and executed during the government of Pedro Pedrossian (1966-1971).
Ironstone is a rock formed by a process of laterization and iron oxidation (Figure 6). Partially-lateritized siltstones possibly belong to the Ponta Grossa Formation, from the Devonian Age, outcropping in the Chapada dos Guimarães. Fine arenites may also occur, which vary from reddish to brown color, and a purplish color when presenting some alteration (Table 1). After oxidation, it may expose the primary structure of the oxidated rock

\section{In situ geodiversity}

Based on previous geological studies of the region (Luz et al. 1980; Alvarenga and Trompette 1993; Migliorini 1999; Silva et al. 2002) and a survey of the geodiversity elements present in the central part of Cuiabá (Costa et al. 2019), it was found that in the Morro do Seminário (the hill where the Church of Nossa Senhora do Bom Despacho (Figure 7) was built, there is a 'reverse fault', typical of areas where a rock deformation activity occurred. Currently, the fault wall

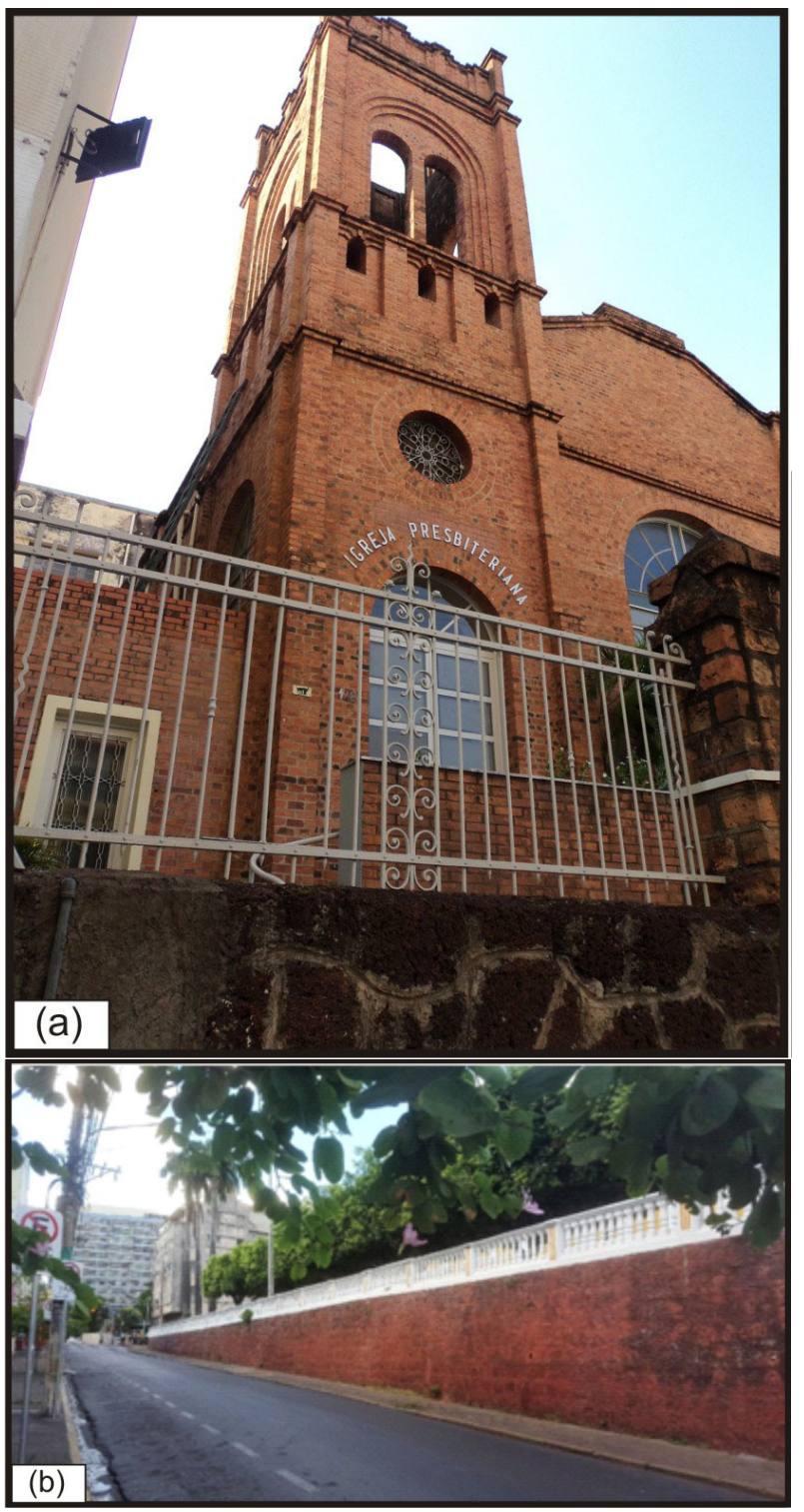

FIGURE 2. (a) Detail of exposed bricks and ironstone wall of the Presbyterian Church of Cuiabá, MT; (b) Back wall of the Instruction Palace, made with ironstone and currently covered with paint (Source: Ana Costa, 2020). 

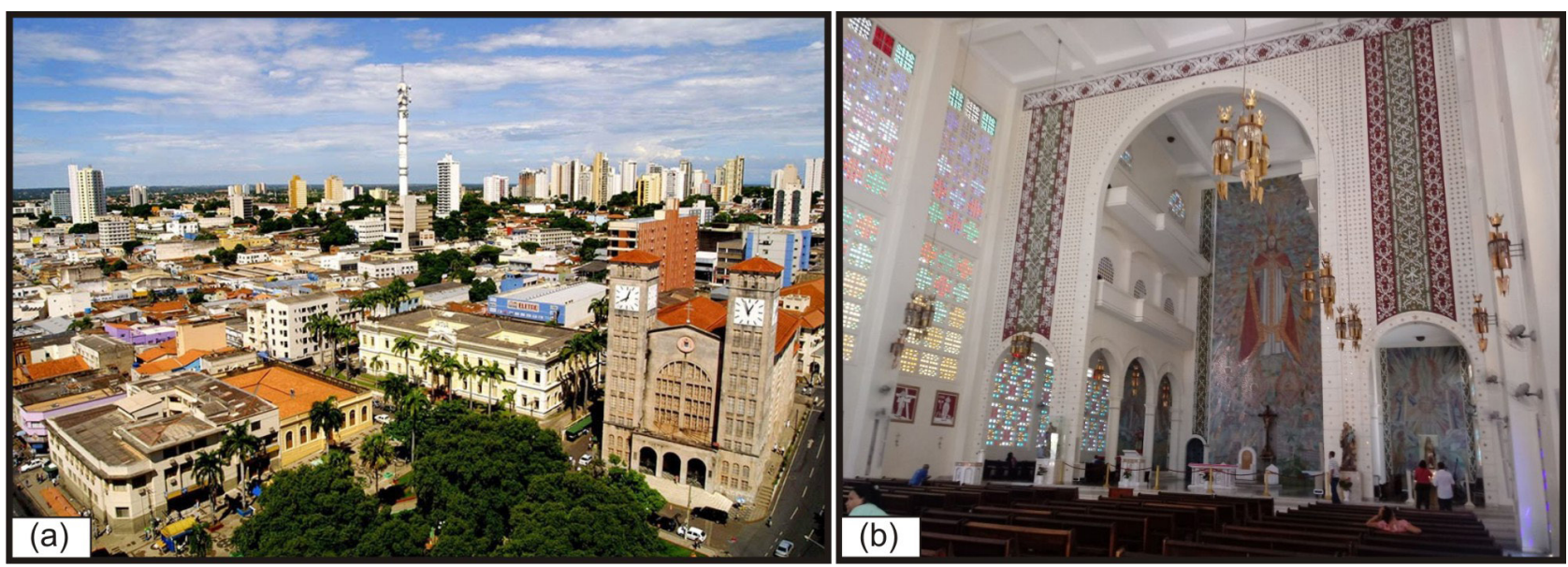

FIGURE 3. (a) At the right side of the image is the Church of Senhor Bom Jesus de Cuiabá, with two towers and clocks (Source: Instituto do Patrimônio Histórico e Artístico Nacional); (b) Detail of the Interior of the Mother Church, showing the altar built with tiny tiles (Source: Amanda Moura, 2017).
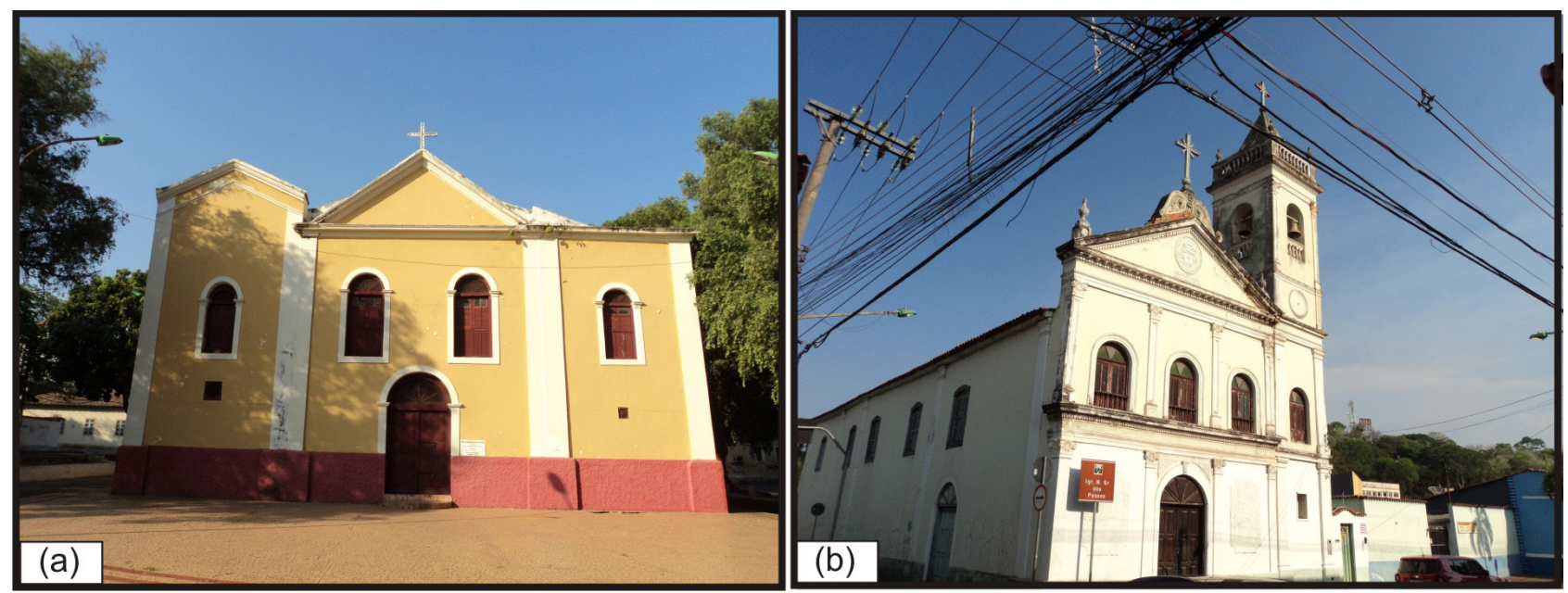

FIGURE 4. (a) Photograph showing the front view of the Church Boa Morte; (b) Also from the colonial period, the Church of Nosso Senhor dos Passos (Source: Ana Costa, 2020).

is covered by a large masonry wall supporting the hill slope, which makes it impossible to observe the fault's structural elements. However, in the continuance of this hill, in the Morro da Luz [in English, Light Hill], it follows in straight line towards the NE until close to the Church of Nossa Senhora do Rosário e São Benedito.

It is, therefore, a unique geosite in downtown Cuiabá (Figure 8) with good intrinsic characteristics (Brilha 2005): small extension, good visibility and studied in a doctorate thesis (Migliorini 1999). Because it is located in the central region, it has association with cultural elements and a preserved flora. With respect to its potential use, it allows that scientific activities be carried out, with good accessibility and no permission to collect materials. It is a place with no interest whatsoever for mineral exploration, if one considers the required protection item. And also in this regard, it is characterized by a high valueadded land that is municipal property.

\section{Conclusions}

Geodiversity is present over the 300 years of Cuiabá's history. Since its discovery in the Coxipó River, gold marks the evolution of city's heritage and history. The metal is still found in quartz veins in the Cuiabá lowlands (Baixada Cuiabana) and continues to be explored in some towns, e.g., Poconé. In this town, according to the Associação Matogrossense dos Municípios (2016), (in English: Association of Mato Grosso Municipalities), in 2015, 1.5 tons of this metal was explored, while the total production in the state (DNPM) was approximately of six tons. Currently, the economy is not supported by gold, but commerce, agribusiness and touristic attractions of urban areas.

The geodiversity in Cuiabá is present in historic buildings, a cultural asset that may become a geotouristic itinerary for an interested public. The ironstone found in the churches and parks represents the utilization of ex situ geodiversity. The hill fault of Morro da Luz can be classified as a singular geosite and represents in situ geodiversity. The cataloging work and characterization of in situ geodiversity within the boundaries of the city, also encompassing the Cuiabá River, and the existing educational outcrops will enable the proposition of new geosites in the region.

The next steps of this research will consist of making an inventory, i.e., listing out and cataloging in situ and ex 

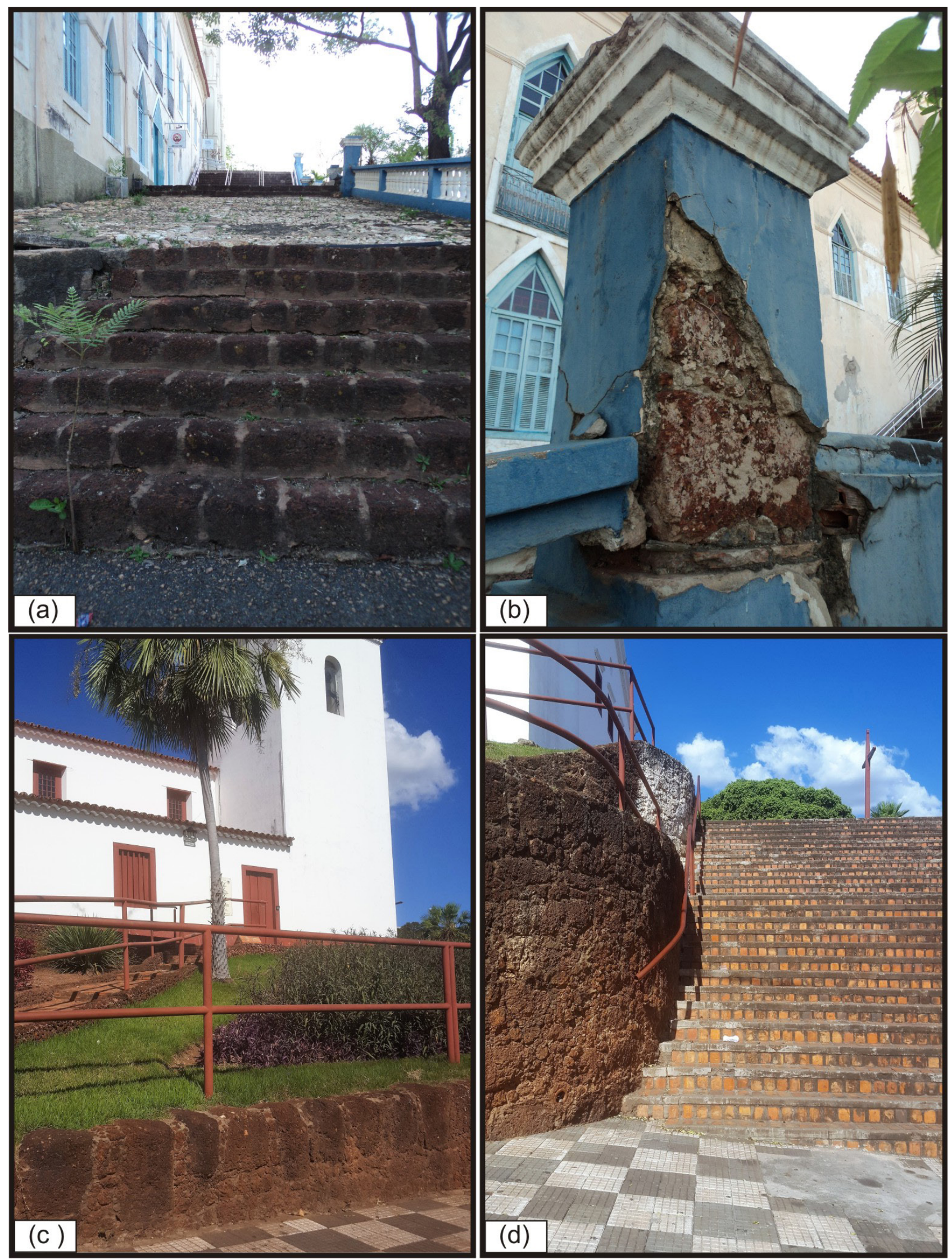

FIGURE 5. (a) and (b). Side stairway and pillar of the old wall of the Church of Nossa Senhora do Bom Despacho; (c) and (d) Protective wall and sideway/stairway, made with ironstone, of the Church of Nossa Senhora do Rosário e São Benedito, Av. Coronel Escolástico (Source: Ana Costa, 2020). 


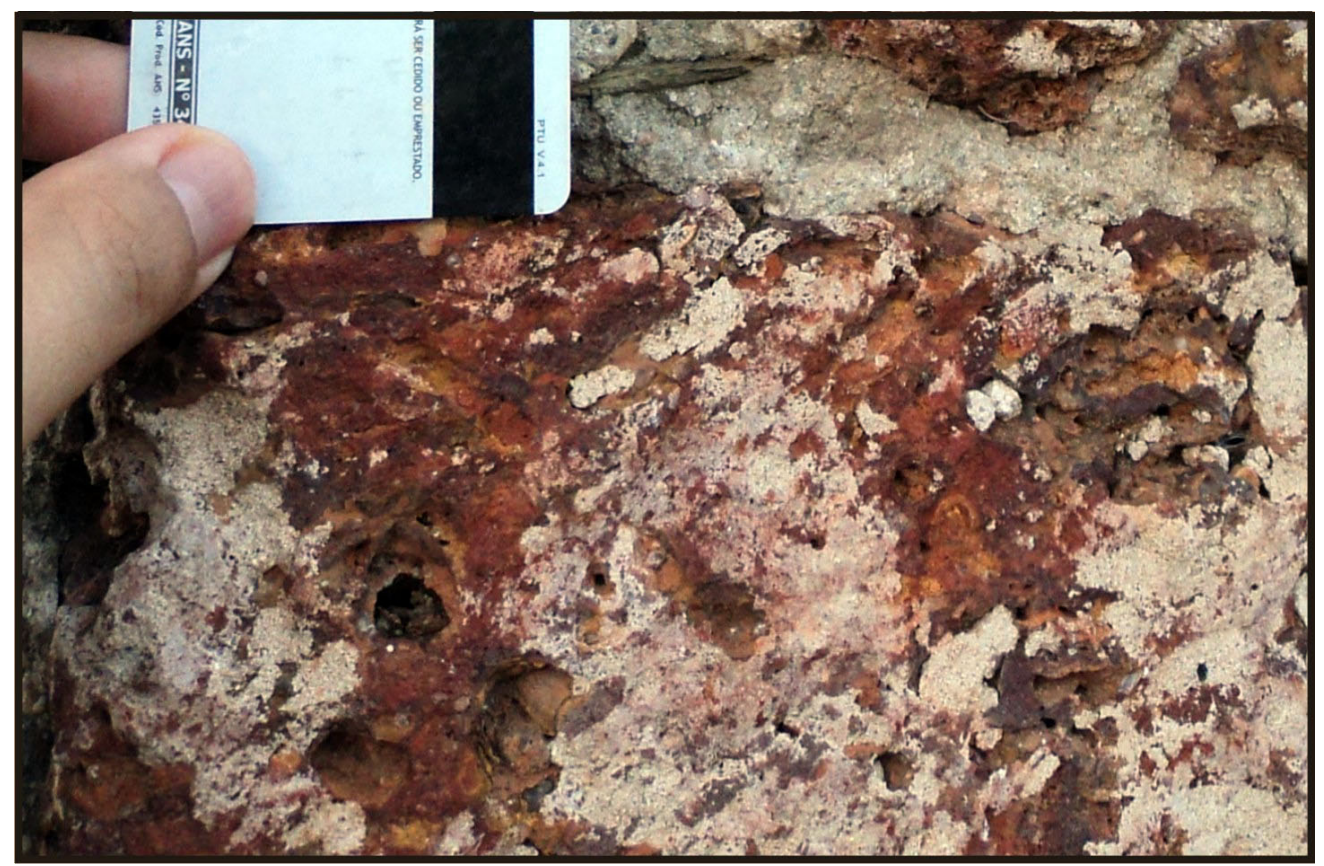

FIGURE 6. Macroscopic detail of ironstone in the column of the Church of Nossa Senhora do Bom Despacho. (Source: Ana Costa, 2020).

TABLE 1. Macroscopic description of ironstone.

\begin{tabular}{l|l|l|l}
\hline Rock & Minerals & Grain size & Nomenclature \\
\hline Ironstone & Goethite, quartz, hematite, Al and Fe hydroxide & Coarse-grained & Ferruginous laterite \\
\hline
\end{tabular}

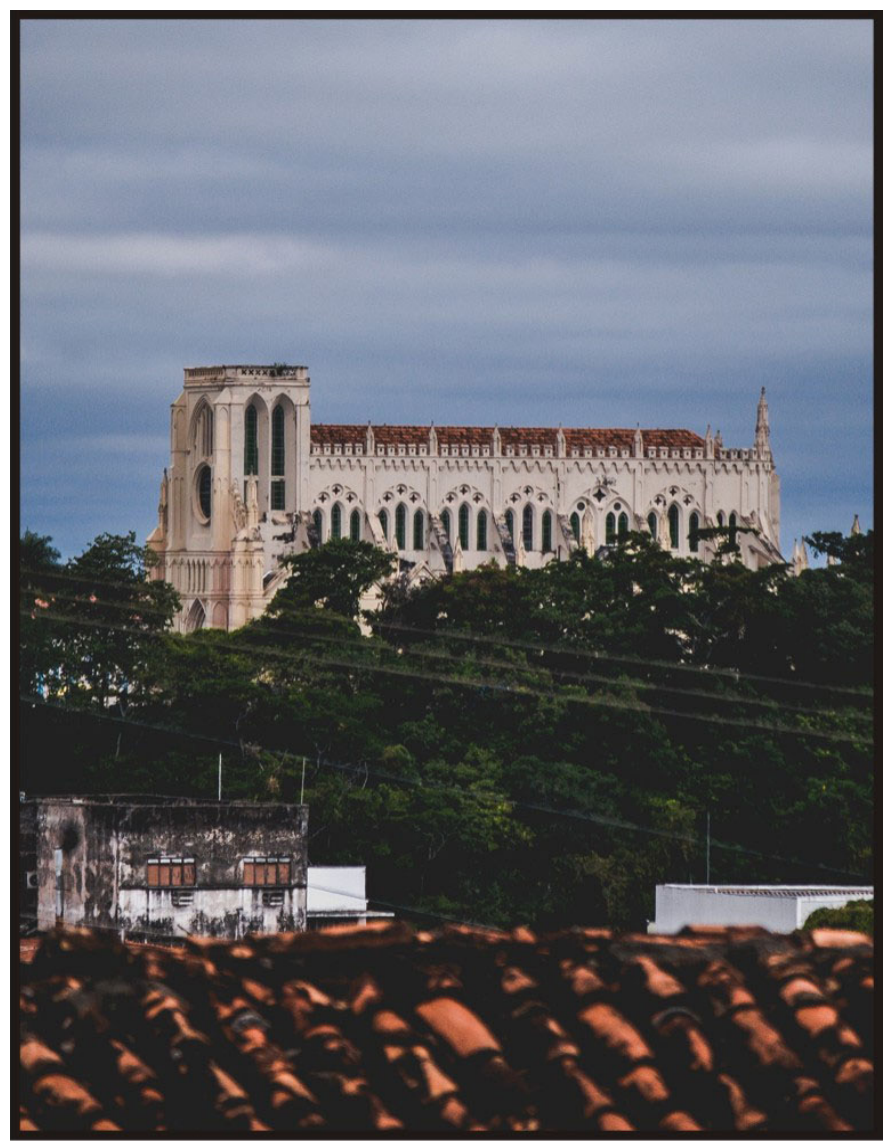

FIGURE 7. Landscape image of the Church of Nossa Senhora do Bom Despacho (Source: Paulisson Miura, 2013. Available on line at: https:// commons.wikimedia.org/wiki/File:Bom_Despacho_(Cuiab\% C3\%A1,_MT,_Brasil)_(9264583453).jpg). 


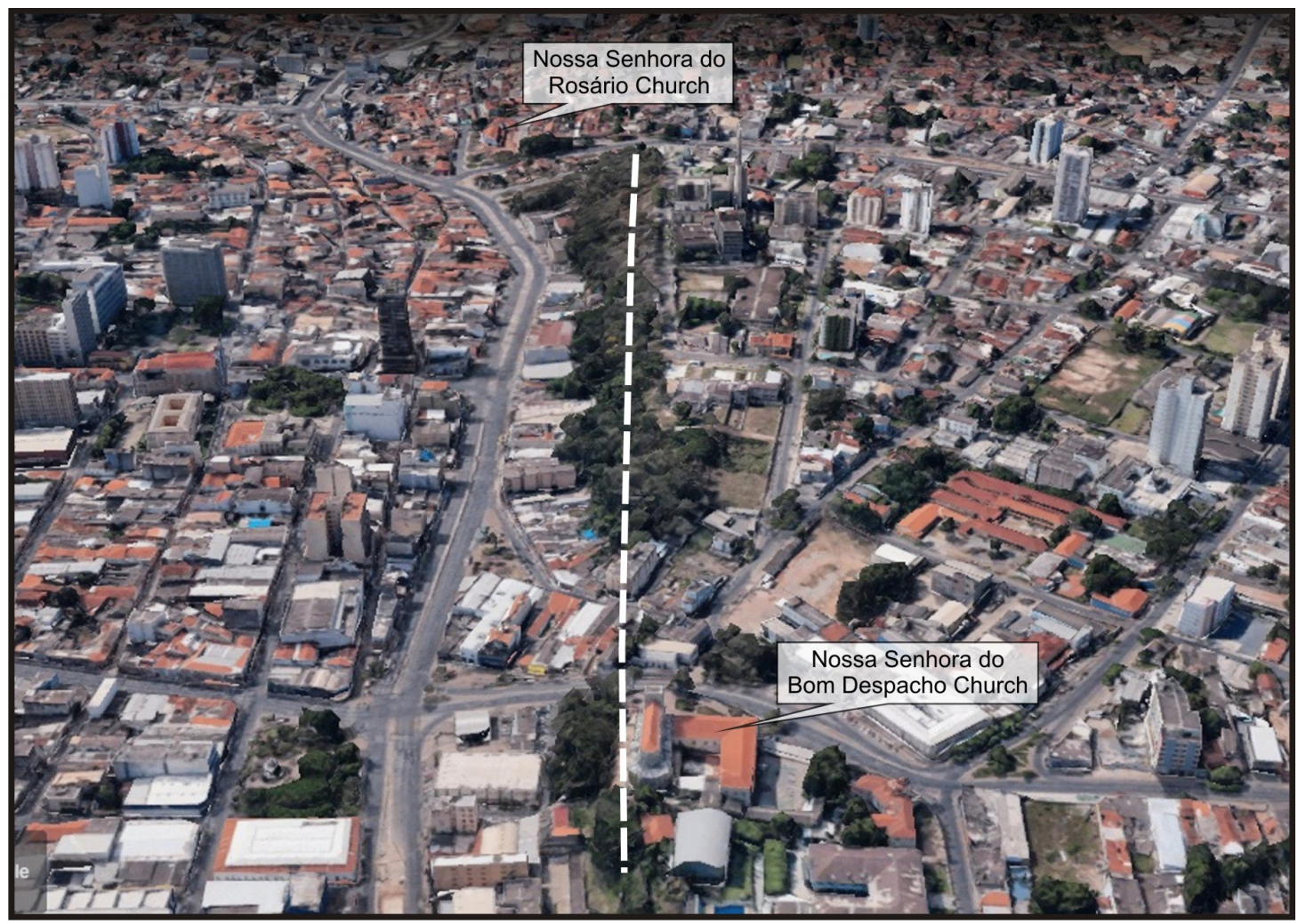

FIGURE 8. Google Earth (2018) (3D) image of the central region, showing the alignment of the Morro da Luz, which translates the reverse fault line (dashed line).

situ elements of geodiversity, to enable the proposition or identification of geosites that could also be part of a geotouristic itinerary.

\section{Acknowledgements}

This article was financially supported by the first author by means of a professor's qualification work supervised by the second author. The authors would like to thank to the JGSB reviewers, who contributed to improve this manuscript.

\section{References}

Alvarenga C.J., Trompette R. 1993. Evolução tectônica brasiliana da Faixa Paraguai: a estruturação da região de Cuiabá. Revista Brasileira de Geociências, 23(1), 18-30. https://doi.org/10.25249/03757536.19932311830

Gazeta Digital. 2017. Arte sacra e histórias peculiares são opções de turismo. Available on line at: https://www.gazetadigital.com.br/ editorias/cidades/arte-sacra-e-historias-peculiares-sao-opcoes-deturismo/524406 / (accessed on 20 May 2021)

Associação Mato-grossense dos Municípios. 2016. Garimpo é alternativa para diversificar a economia nos municípios. Available on line at: https://www.amm.org.br/Noticias/Garimpo-e-alternativapara-diversificar-a-economia-nos-municipios / (accessed on 20 May 2021)

Brilha J. B. 2005. Patrimônio geológico e geoconservação: a conservação da natureza na sua vertente geológica. Viseu, Palimage, $190 \mathrm{p}$.

Conte C.Q., Freire M.V.L. (org.). 2005. Centro Histórico de Cuiabá: patrimônio do Brasil. Cuiabá, Entrelinhas, 100 p.
Costa A. C. D., Nascimento M. A. L., Silva C. H., Migliorini R. B. 2019. História da Geodiversidade em 300 anos de Cuiabá-MT - Centro Histórico da Cidade do Ouro. In: Simpósio Brasileiro de Patrimônio Geológico, 5. Available on line at: http://www.urca.br/vsbpg/wpcontent/uploads/2020/03/Anais-VSBPG-2019.pdf / (accessed on 20 May 2021)

Del Lama E.A. 2019. Potential for Urban Geotourism: churches and cemeteries. Geoheritage 11, 717-728. https://doi.org/10.1007/s12371018-0325-9

Instituto do Patrimônio Histórico e Artístico Nacional. Cuiabá (MT). Available on line at: http://portal.iphan.gov.br/pagina/detalhes/368/ / (accessed on 24 May 2021)

Luz J.S., Araujo E.S., Godoi H.O. 1980. Projeto Coxipó: Relatório Final Fase 1. Goiânia, DNPM/CPRM, 136 p. Available on line at: https:// rigeo.cprm.gov.br/ispui/handle/doc/9169 / (accessed on 27 May 2021)

Google Earth. 2018. Mapa urbano de Cuiabá-MT. Available on line at: http://earth.google.com / (accessed on 20 May 2021)

Migliorini R.B. 1999. Hidrogeologia em meio urbano. Região de Cuiabá e Várzea Grande-MT. PhD Thesis, Instituto de Geociências, Universidade de São Paulo, 146 p. https://doi.org/10.11606/T.44.2000. tde-15102014-100504

Nascimento M.A.L. Silva M.L.N., Bezerra G.B. 2018. Presença da geodiversidade em itinerário geoturístico no centro histórico de Natal/ RN (NE Brasil). Terra Plural 12(2), 238-253. http://dx.doi.org/ 10.5212/ TerraPlural.v.12i2.0006

Silva C.H., Simões L.S.A., Ruiz A.S. 2002. Caracterização estrutural dos veios de quartzo auríferos da região de Cuiabá (MT). Revista Brasileira de Geociências, 32(4), 407-418. https://doi.org/10.25249/03757536.2002324407418

Silva M. L. N, Nascimento M. A. L. 2016. Panorama geral sobre a geoconservação em Natal (RN): ameaças à geodiversidade in situ e ex Situ. HOLOS, 32(7), 3-14. https://doi.org/10.15628/ holos.2016.4743 
